\title{
Bitki Yüzeyinin Enerji Dengesi Bileșenlerinin Belirli Fenolojik Aşamalarda Analizi
}

\section{Analysis of the Energy Balance Components of Vegetation during Particular Phenological Stages \\ Barış Çaldắ ${ }^{*}$}

${ }^{1}$ Istanbul Teknik Üniversitesi Uçak ve Uzay Bilimleri Fakültesi Meteoroloji Mühendisliği Bölümü, 34469 Maslak, Istanbul, TÜRKIYE

Sorumlu Yazar / Corresponding Author*: caldagb@itu.edu.tr

\author{
Geliș Tarihi / Received: $30.07 .2018 \quad$ DOI:10.21205/deufmd.2019216110 \\ Kabul Tarihi / Accepted: 13.09.2018 Araştırma Makalesi/Research Article
}

Atıf șekli/How to cite: CALDAĞ, B. (2019). Bitki Yüzeyinin Enerji Dengesi Bileșenlerinin Belirli Fenolojik Așamalarda Analizi. DEUFMD, 21(61), 97-105.

$\ddot{0 ̈ z}$

İklim değişiminin sıcaklık artışları, yağışların azalması, artan buharlaşma gibi etkileri; geniş alanda yetiștirilen bitki türlerinin su ihtiyacına ve üretim değerlerine yönelik çalıșmalar için önemlidir. Bitki su tüketimi (evapotranspirasyon) verisi, bir bölgede yapılması planlanan tarımsal sulama projelerinin temelini oluşturmaktadır. Yüzeyler ile atmosfer arasındaki su döngüsünü idare eden yüzey enerji dengesi bileșenlerinin saptanması da bu noktada bir ihtiyaç halini almaktadır. Yüzey enerji dengesi bileşenlerinin saptanması amacıyla yaygın olarak kullanılan Bowen Oranı Enerji Dengesi (Bowen Ratio Energy Balance, BREB) Yöntemi, bu çalıșmada kanola yüzeyi üzerine uygulanmıştır. Bu kapsamda Kırklareli Atatürk Toprak Su ve Tarımsal Meteoroloji Araştırma Enstitüsü Müdürlüğü deneme alanında 2016 gelişme döneminin çiçeklenme aşamasında buharlaşma gizli ısı akısı, toprak ısı akısı, net radyasyon, hissedilir ısı akısı ile bitki yüzeyinin normalleştirilmiş fark vejetasyon indeksi (Normalized Difference Vegetation Index, NDVI) belirlenerek, ölçülen bileșenler ile hesaplanan bileșenler arasındaki ilișkiler araștırılmıștır. Sonuçta ölçüm dönemi içinde net radyasyon değerinin en yüksek olduğu tarih; 27 Nisan 2016 olarak belirlenmiştir. $\mathrm{Bu}$ tarih, seçilen günler için hesaplanan evapotranspirasyon değerlerinin de en yüksek olduğu zaman aralığı içindedir. Aynı dönemin NDVI değerlerinin de benzer biçimde 22 Mart14 Nisan 2016 arasında maksimum değerlere ulaştı̆̆ı belirlenmiştir.

Anahtar Kelimeler: İklim Değişimi, evapotranspirasyon, Bowen Oranı Enerji Dengesi, Bitki Yüzeyinin Normalleștirilmiş Vejetasyon Índeksi

\begin{abstract}
Reliability of data on crop water consumption (evapotranspiration) is the basis of the irrigation plans for agricultural purposes. Major effects of climate change such as increasing temperatures and evaporation, precipitation decrease are crucial for studies on water demand and yields of widely grown crop types. Determination of the surface energy components controlling the water cycle between surfaces and the atmosphere also becomes a need at this point. In this study, a common method on the determination of the surface energy budget; namely the Bowen Ratio Energy Balance (BREB) approach was applied on a canola surface during a particular growing stage (flowering) of the crop. In this context; latent heat flux of evapotranspiration, net radiation, sensible heat flux and the Normalized Difference Vegetation Index (NDVI) values were evaluated to search for possible
\end{abstract}


relationships between the measured and calculated values of the corresponding components. The results showed that the date (27 April 2016) represented with highest net radiation value took also part within days of relatively higher evapotranspiration amounts. Also the NDVI values of the same measurement period reached their maximum rates for between 22 March and 14 April 2016.

Keywords: Climate Change, evapotranspiration, Bowen Ratio Energy Balance, Normalized Difference Vegetation Index

\section{Giriş}

Yașamsal bir faktör olmasının yanı sıra suyun tarım ekonomisine de önemli etkileri vardır. İklim değișimi kaynaklı küresel ısınmanın bir sonucu olarak su kaynakları miktar ve kalite bakımından yetersizleşmektedir. Artan nüfus ve su kaynaklarının bilinçsiz kullanımı da ülkeleri alternatif sulama yöntemleri bulmaya yönlendirmektedir. $\mathrm{Bu}$ bağlamda sulamanın miktar ve zamanlamasına yönelik programlar, su kaynaklarının verimli kullanılması için yaygınlaşmaktadır. Bunun için de bitki su tüketiminin (evapotranspirasyon) bilinmesi gerekir [1]. Evapotranspirasyon; yüzey enerji dengesinin de önemli bir bileșenidir.

Bitki su tüketiminin doğrudan ölçümlerle hesaplandığı lizimetre gibi uygulamaların yanı sıra, yüzey enerji dengesinin dikkate alındığı mikrometeorolojik yöntemler günümüzde tercih edilmeye başlanmıştır. Söz konusu yöntemlerden olan BREB, bitki su tüketiminin yüksek olduğu bir gelișme döneminde kanola bitki yüzeyi üzerindeki enerji dengesi bileșenleri bağlamında bu çalıșmada analiz edilmiștir. Uygulaması kolay ve maliyeti düşük olması sebebiyle küresel ölçekte uygulama alanına sahip bulunan BREB Yöntemi'nde hissedilir ısı akısı $(\mathrm{H})$ ve buharlaşma gizli ısı akısı (LE) arasında belli bir oran olduğu belirlenerek, bu değer Bowen Oranı $(\beta)$ olarak adlandırılmaktadır [2].

Dünyada yüzeyler ile atmosfer arasındaki enerji alışverişlerine yönelik çok sayıda araştırma yapılmış ve yapılmaktadır. Nemli toprak koşullarında BREB yönteminin doğrudan lizimetre ölçümleri ile test edildiği bir çalıșmada, hesaplanan değerlerle ölçüm sonuçlarının birbirine oldukça yakın olduğu saptanmıștır [3]. Yonca bitkisinin BREB yöntemi ve lizimetre ölçüm sonuçlarının karşılaştırıldığı bir çalışmada, Bowen Oranı'nın sıfırın altında olduğu sıcak ve rüzgârlı günler ile buharlaşma gizli ıSı akısının kullanılabilir enerjiyi aştığı koșullar için iki yaklașımdan elde edilen sonuçların farklılığı vurgulanmıştır [4]. Farklı sulama koşullarının pamuk bitkisinin su tüketimine etkilerine yönelik Türkiye'de yapılan ilk çalışmada özellikle su kısıtı uygulanan örnekler için BREB ile ölçüm değerleri arasında kabul edilebilir bir yaklaşım olduğu belirlenmiștir [5]. BREB yaklașımının, mera yüzeylerinin karbondioksit akılarının tahmininde ve bir modelleme yöntemi olarak kullanılabileceğine dair bir çalışma da, IdahoABD'de gerçekleştirilmiştir [6]. Göl yüzeyleri üzerinde hassas su terazisi kullanılarak yapılan ölçümlerin kullanıldığı bir modelleme çalışmasında, BREB Yöntemi ile buharlaşma isı akısı ve hissedilir ısı akısı değerleri hesaplanmıștır. Çalışmada kararsız atmosfer koşulları ile Bowen Oranı'nın minimum değerleri arasındaki ilişki ortaya konmuştur [7]. Brezilya'da üzüm bağlarında yürütülen bir araştırma çalışmasında, BREB Yöntemi'nin damla sulama uygulaması altında geçerliliği dört farklı yaklaşımla test edilmiştir [8]. Mısır bitkisinin transpirasyonundan kaynaklanan buharlaşma gizli ısı akısının, yüzeyin toplam evapotranspirasyonunun gizli ısı akı miktarı ile ilișkisinin incelenmesine yönelik Japonya'da yürütülen bir araștırmada BREB ve ağırlıklı lizimetre ölçüm sonuçları karşılaştırmalı olarak ortaya konmuş ve sonuçta BREB yaklaşımının özellikle bitkinin su kullanım etkinliğinin arttırılması araștırmalarında tercih edilebilir olduğu saptanmıștır [9]. Yine üzüm bağları üzerinde yürütülen, ancak doğrudan ölçümlerden farklı olarak BREB Yöntemi'nin model sonuçları ile karşılaştırılması yoluna gidilen bir başka çalıșma Kuzeybatı Çin'de kurak yüzeyler üzerinde gerçekleştirilmiştir. Ölçümleri hesapla birleștiren BREB yaklaşımının, model sonuçlarına nazaran tercih edilebilir olduğu anlașılan bu çalıșmada, aletler seçilirken ve arazide konumlandırılırken gösterilen özenin BREB sonuçlarının hassasiyetine doğrudan ve olumlu etkidiği görülmüştür [10].

BREB'e nazaran ileri teknoloji gerektiren Eddy Kovaryans (Eddy Covariance, EC) Yöntemi ile elde edilen hissedilir ısı akısı ve buharlașma gizli ısı akısı değișkenlerinin, ekstrem ölçüm koşulları dışında birbirine yakın sonuçlar 
DEU FMD 21(61), 97-105, 2019

verdiği de güncel bir çalıșmada gözlenmiștir [11]. Günlük BREB değerlerinin ağırlıklı tip lizimetre ölçüm sonuçlarından daha geçerli olduğu çalışma sonuçlarına örnek olarak Türkiye'de yürütülen bir çalışma, sulama uygulanan soya fasulyesi arazisi üzerinedir [12]. Türkiye'de buğday yetiştirilen bir arazi üzerinde BREB Yöntemi sonuçlarının lizimetre ölçümleri ile karşılaştırıldığı bir başka çalıșmada, bitkinin mevsimlik su tüketiminin mikrometeorolojik yaklașımla lizimetre sonuçlarını \%99 oranında temsil edebildiği görülmüştür [13]. Zamansal ve alansal olarak farklı yoğunlukta kapalılığa sahip dört farklı yüzey (çim ve çalı) yüzey üzerinde BREB Yöntemi kullanılarak yürütülen çok yıllık bir evapotranspirasyon belirleme araştırması, ekilebilir arazilerle otlak arazilerin toplam buharlaşma miktarlarında birbirlerine önemli ölçüde yakınsadığını göstermiştir [14] Meteorolojik parametrelerin eğilimlerindeki mevsimsel değişimlerin enerji akılarına etkisinin BREB Yöntemi ile ormanlarda incelendiği bir araştırmada Bowen Oranı'nın kışın yaza oranla yüksek değerler gösterdiği anlaşılmıştır. $\mathrm{Bu}$ durumun, özellikle kışın gerçekleşen düşük atmosfer ve yüzey sıcaklıkları ile yine düșük net radyasyon değerleri nedeniyle buharlaşmanın baskılanmasından kaynaklandığ vurgulanmıștır [15]. BREB yaklașımının doğruluğunun test edildiği bir çalıșmada hava sıcaklığı ve bağıl nemin gradyanlarının temsili için 13 farklı seviyede kuru ve rslak hazne sıcaklık kaydı tutulmuş, sonuçlar bir EC sisteminin çıktıları ile karşılaştırılarak, profilde artan ölçüm seviyesi sayısının, sonuçların hassasiyetine olumlu etkisi ortaya konmuștur [16].

Uzaktan algılama tekniğinin ve NDVI verisinin bitki yüzeylerinin incelenmesi amaciyla yapılmış çok sayıda ulusal ve uluslararası araștırma mevcuttur $[17,18]$. Özellikle NDVI ile vejetasyon dinamikleri arasındaki ilişkilerin ortaya konmasına dayanan çalıșmalar onlarca yıllık geçmişe sahiptir $[19,20]$. Söz konusu araştırmalara uluslararası [21] ve ulusal [22] çerçevede günümüzde de çeşitli örnekler verilebilir.

Bu çalışmanın amacı, buharlaşma kayıplarının görece önemli olduğu Türkiye gibi yarıkurak ülkelerde su verimliliğinin artırılmasının önemine pratik bir örnekle dikkat çekmektir. Su kullanım verimliliğinin arttırılması ve bu bağlamda önemli bir kayıp bileșeni olan buharlaşmanın, doğru ölçüm ve hesap yaklaşımlarıyla ele alınması, bir ihtiyaçtır. Konu ile ilgili küresel ölçekte geçerliliğe sahip mikrometeorolojik yöntemlerden olan Bowen Oranı Enerji Dengesi Yöntemi, bu çalıșmada seçilmiş ve kanola ile kaplı yüzey için enerji dengesi bileşenleri ile yüzeyin vejetasyon indeksi (NDVI) eşzamanlı olarak analiz edilmiștir. Veriler, İstanbul Teknik Üniversitesi Meteoroloji Mühendisliği Bölümü Tarımsal Meteoroloji Ekibi tarafından, Kırklareli'nde Atatürk Toprak Su ve Tarımsal Meteoroloji Araştırma Enstitüsü Müdürlüğü arazisinde kurulan ve ilgili araştırma enstitüsü ile birlikte yürütülen araştırma projesine ait ölçüm sistemlerinden temin edilmiştir.

\section{Materyal ve Metot}

BREB yaklaşımı, buharlașma ve enerji akısı ölçümlerinde lizimetre yöntemine nazaran fazla sayıda hesaplama içeren, dolaylı bir tekniktir. Yöntem; farklı seviyelerde ölçülen hava sıcaklığı ve nem değerlerinden elde edilen farkları, net radyasyon ve toprak ısı akısı ölçümleri ile birlikte dikkate alarak, yüzeylerin buharlaşma gizli ısı akısını tahmin etmektedir [23].

\subsection{Araştırma alanının ve kurulu ölçüm sisteminin özellikleri}

Trakya Bölgesi'nde, birim alana düşen verim bakımından özellikle mısır, ayçiçeği, çeltik ve buğday için ülkemiz ortalamalarının üzerinde ortalama değerlere ulaşılmaktadır. Bölgede yer alan ve çalışmanın gerçekleştirildiği il olan Kırklareli, $41^{\circ}-42^{\circ}$ kuzey enlemleri ile $26^{\circ}-41^{\circ}$ doğu boylamları arasında konumlanmıştır. Kırklareli, ülkemizde özellikle buğday, ayçiçeği ve misır üretiminde önemli rol oynayan iller arasındadır. İlin deniz seviyesinden yüksekliği yaklaşık olarak 203 m olup, uzun yıllık ortalama sıcaklık ve toplam yağış değerleri sırasıyla 15.5 ${ }^{\circ} \mathrm{C}$ ve $540 \mathrm{~mm}$ 'dir. Deneme alanı, Kırklareli Atatürk Toprak Su ve Tarımsal Meteoroloji Araştırma Enstitüsü Müdürlüğü arazisi içinde yer almaktadır (Şekil 1). 

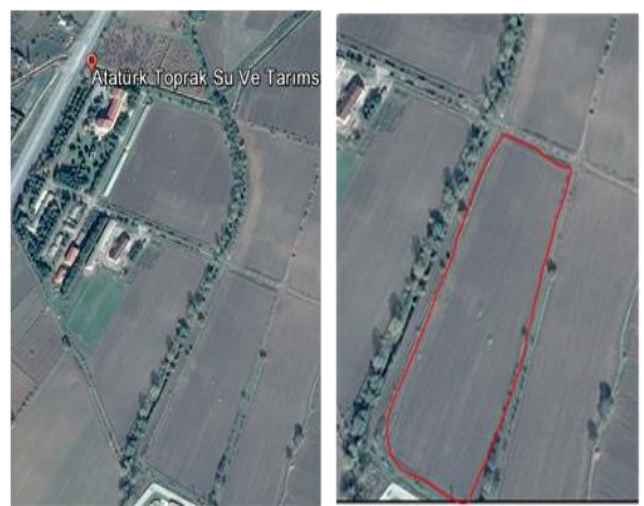

Șekil 1. Verinin Sağlandığı Kurumun ve Araștırma Alanının Konumu [24, 25].

Bu çalışmada, bölgede ekim alanı son yıllarda genişleyen kanola bitkisine ait bir yüzey üzerinde 2015-2016 gelişme dönemi içinde BREB yaklaşımı kullanılarak enerji dengesi bileșenleri incelenmiştir. Arazideki sistem, İTÜ Meteoroloji Mühendisliği Bölümü Tarımsal Meteoroloji araştırma grubu tarafindan yürütülen bir TÜBITTAK Projesi için daha önceden kurulmuş bir tarımsal meteoroloji istasyonu ile bütünleşik haldedir. Arazinin yaklaşık büyüklüğü $25000 \mathrm{~m}^{2}$ civarında olup, hâkim rüzgâr doğrultusundaki feç mesafesi 180 m'dir. Calışmanın verisinin temin edildiği bu sistem $8 \mathrm{~cm}$ toprak derinliğinde 2 adet toprak ısı akısı ölçer; yerden $2 \mathrm{~m}$ yükseklikte net radyasyon ölçer ile global solar radyasyon ölçer; 2 ve $3 \mathrm{~m}$ yüksekliklerde sıcaklık ve bağll nem ölçerler; $0.5,1,2,5$ ve $10 \mathrm{~m}$ yüksekliklerde rüzgar hızı ölçerler; ayrıca $2 \mathrm{~m}$ yükseklikte rüzgar yön ölçer ve $1 \mathrm{~m}$ yükseklikte de yağış ölçerden ibarettir (Şekil 2). Rüzgar hızı ölçerler arazinin hakim rüzgar yönü doğrultusunda konumlandırılırken, BREB Yöntemi'nin bu noktada ihtiyaç duyduğu minimum feç mesafesi koşulu da uluslararası standartlara uygun biçimde sağlanmıştır [24]. Belirtilen sensörlerden gelen saniyelik veri 10 ve 30 dakikalık ortalamalar halinde bir veri depolayıcı tarafından kaydedilmiştir.

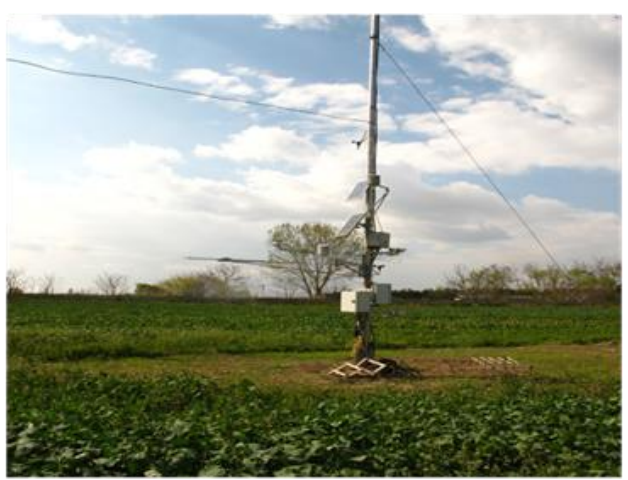

Şekil 2. Kanola Arazisinde Kurulu BREB Sistemi $[24,25]$.

Sistemin veri toplayıcısına monte edilen NDVI sensörü de aşağıdaki Şekil 3'te verilmiștir.

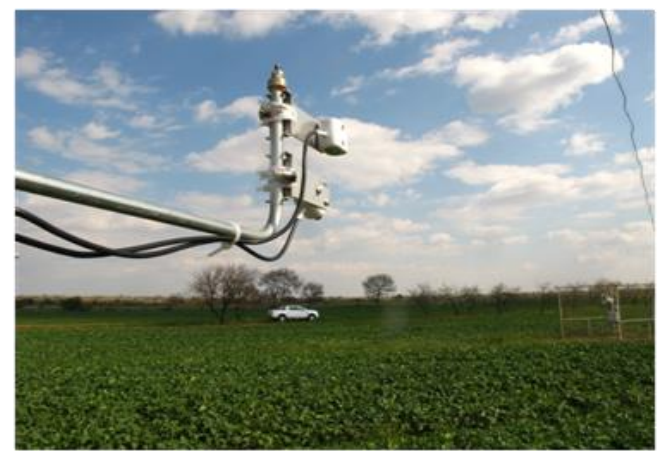

Şekil 3. Yakın Kızıl Ötesi (NIR) ve Görünür Bölge Spektral Özellikleri (VIS) Ölçen Sensörler.

Şekil 3'te görülen sistem, NIR ve VIS dalga boylarında yüzeyin yansıtma değerlerini eşzamanlı olarak ölçebilmektedir.

\subsection{BREB yöntemi ve NDVI verisi}

BREB Yöntemi, yüzeylerin buharlaşma gizli ısı akısı (LE) ile hissedilir gizli ısı akılarının (H), ölçüm ve hesap kombinasyonuyla belirlenmesine dayanan; uluslararası kabul görmüş bir yaklaşımdır. LE ile $\mathrm{H}$ arasındaki oran, Bowen Oranı ( $\beta$ ) olarak adlandırılmaktadır [2]. Özellikle adveksiyonsuz koşullarda yüzeyin isı enerjisi alıșverișini (herhangi bir aerodinamik özelliğin bilinmesine ihtiyaç duymadan) belirlemekte kullanışlı olması bakımından BREB Yöntemi avantajlıdır ve geniş alanlarda kullanıma uygundur $[4,26]$. Yöntemin avantajları arasına ölçüm verisinin frekans yüksekliği, kolay kurulum ve düşük maliyet özellikleri de dâhil edilebilir. Yüzeylerin enerji akılarının takibinde kullanılan diğer yöntemlerden daha dolaylı bir yöntem olan BREB, hava sıcaklığını, nem gradyanlarını, 
DEU FMD 21(61), 97-105, 2019

net radyasyonu ve toprak-ısı akı ölçümlerini kullanarak gizli ısı akısını belirlemektedir [25, 27]. Bunlar arasında sensörlerin yerleștirileceği yükseklikler ve sistemin arazideki yerinin belirlenmesi sayılabilir. Zira BREB ölçümlerinde hakim rüzgar doğrultusunda yeterli feç mesafesine ihtiyaç vardır [4]. Alansal olarak yüzey koşullarının heterojenleștiği koşullar, zamansal olarak ise gün doğumu ve batımı sırasındaki özel koșullar, BREB yaklașımının doğruluğunu sınırlayıcı durumlardır [26].

Yöntemin yukarıda değinilen fiziksel temelinin matematiksel ifadesi, așağıda verilen 1-4 numaralı eşitlikler ile özetlenmiştir:

$\mathrm{R}_{\mathrm{n}}=G+H+L E$

Eşitlik 1'de $R_{n}$, net radyasyonu $\left(W / m^{2}\right) ; G$, toprak ısı akısını $\left(\mathrm{W} / \mathrm{m}^{2}\right) ; \mathrm{H}$, hissedilir ısı akısını $\left(\mathrm{W} / \mathrm{m}^{2}\right)$ ve LE, buharlaşma gizli ısı akısını $\left(\mathrm{W} / \mathrm{m}^{2}\right)$ göstermektedir. Ölçümlerle Bowen Oranı'nın elde edildiği hesap aşaması, Eşitlik 2'de sunulmuştur:

$$
\beta=\gamma\left[\frac{T_{1}-T_{2}}{e_{a 1}-e_{a 2}}\right]=\frac{H}{L E}
$$

Burada $\beta$, Bowen oranını; $\gamma$, psikometrik katsayılı $\left(\mathrm{kPa} /{ }^{\circ} \mathrm{C}\right) ; \mathrm{T}_{1}$, birinci (alt) seviyedeki hava sıcaklığını $\left({ }^{\circ} \mathrm{C}\right) ; \mathrm{T}_{2}$, üst seviyedeki hava sıcaklığını $\left({ }^{\circ} \mathrm{C}\right)$; $\mathrm{e}_{a 1}$, alt seviyedeki havanın gerçek buhar basıncını (kPa); $e_{a}$, üst seviyedeki havanın gerçek buhar basıncını $(\mathrm{kPa})$ temsil eder. Hissedilir ısı akısının, buharlaşma gizli ısı akısına oranına dayanan Bowen Oranı değerlerinin 1'den büyük olması kurak koşulları gösterirken, 1'den küçük değerler ise sulak, nemli yüzeyleri temsil etmektedir.

LE değerinin Bowen Oranı ile hesabı da aşağıdaki Eşitlik 3 ile verilmiştir:

$$
L E=\frac{R_{n}-G}{1+\beta}
$$

$\mathrm{Bu}$ temel eşitliklerin yanı sıra, Eşitlik 2'de verilen Bowen Oranı'nın ( $\beta$ ) elde edilmesi için ihtiyaç duyulan ara hesap aşamaları da bulunmaktadır. Söz konusu süreç; doymuş ve gerçek buhar basınçlarının, psikrometrik katsayının ve buharlaşma gizli ısısının elde edilmesini içermektedir.

Bitki yüzeyinin güneș radyasyonunu elektromanyetik spektrumun farklı aralıklarında eşzamanlı olarak absorblaması ve yansıtması temeline dayanan NDVI verisi de çalışmada ölçülerek ele alınmıştır. NDVI bu bağlamda yakın kızılötesi bölge ile görünür bölge radyasyonu arasındaki ilişkiyi temsil etmektedir [21].

$$
N D V I=\frac{(N I R-V I S)}{(N I R+V I S)}
$$

Bilindiği üzere sağlıklı bitki yüzeyleri görünür bölge radyasyonunu önemli oranda absorblayarak fotosentezde kullanırken, yakın kızılötesi aralığına denk gelen güneş radyasyonunu ise yansitmaktadır. NDVI, bu özelliği ile bitkilerin sağlık ve gelişme durumunun incelenmesi amaçlarına hizmet etmektedir.

Net radyasyon yüzeydeki gelen-giden kısa ve uzun dalga boylu radyasyonlar arasındaki farkı gösterirken, NDVI yakın kızlötesi ile görünür bölge yansıtmalarının farkına dayanır. Bitkinin fenolojik aşamalarından çiçeklenme zamanına denk gelen süreçte bu iki değişken incelendiğinde, çevresel faktörlerin bunlar arasında doğrusal bir ilişki kurulmasını zorlaștırabileceği anlașılmıștır. Yağıșın olmadığı ancak kapalılığın hâkim olduğu günler ile, NDVI değerlerinin azalıș gösterdiği günlerin aynı günler olduğu da ayrıca gözlenmiştir.

\section{Bulgular}

\subsection{Enerji akı bileșenlerinin analizi}

İncelenen kanola bitkisi araziye 15.10.2015 tarihinde ekilmiştir. Toprak yüzeyine 3.11.2015'te çlkan bitki, gelişimini 258 günde tamamlayarak 28.6.2016'da hasad edilmiștir. $\mathrm{Bu}$ çalıșmada, bitkinin gelișme döneminin generatif evresi içinde su tüketiminin yoğun olduğu iki fenolojik aşama (2. yaprak çifti ve çiçeklenme) analiz edilmiştir.

Kanola bitki yüzeyi üzerinde Mart-Nisan 2016 döneminde ölçülen tarımsal meteorolojik verinin bileşenleri net radyasyon, hava sıcaklığı, yağıș, bağıl nem ve toprak ısı akısı olmuștur. Bu zaman diliminde bitki yüzeyinden $1 \mathrm{~m}$ yukarıda belirlenen ortalama hava sicaklığ $12.1{ }^{\circ} \mathrm{C}$ 'dir. $\mathrm{Bu}$ değişken için minimum ve maksimum değerler ise sırasıyla 4.4 ve $18.8{ }^{\circ} \mathrm{C}$ olarak kaydedilmiştir. Bitki yüzeyinden $2 \mathrm{~m}$ yükseklikte ölçülen ortalama, minimum ve maksimum sıcaklıklar ise aynı dönemde sırasıyla $11.9, \quad 4.1$ ve $18.7{ }^{\circ} C^{\prime}$ 'dir. Kanola yüzeyinden 1 ve 2 m yükseklikte ölçülen ortalama bağıl nem değerleri bu dönemde \% 82.8 ve \% 79.3 olmuştur. Bu iki aylık zaman 
DEU FMD 21(61), 97-105, 2019

aralığının en yağıșlı günü olan 26 Nisan 2016 tarihinde kaydedilen miktar, 30.2 mm'dir. Ölçüm döneminde (1.3.2016-30.4.2016) elde edilen enerji dengesi bileșenlerinin çiçeklenme öncesi ve çiçeklenme sırasındaki bazı istatistikleri, aşağıdaki Tablo 1'de verilmiştir.

Tablo 1. Enerji Akılarının İncelenen Dönemdeki İstatistikleri $\left(\mathrm{W} / \mathrm{m}^{2}\right)$.

\begin{tabular}{|c|c|c|c|c|c|c|}
\hline & \multicolumn{3}{|c|}{ Çiçeklenme Öncesi } & \multicolumn{3}{c|}{ Çiçeklenme Sırasında } \\
\cline { 2 - 7 } & Ort. & Mak. & Min. & Ort. & Mak. & Min. \\
\hline $\mathrm{R}_{\mathrm{n}}$ & 63.1 & 117.4 & -5.8 & 107.8 & 160.9 & 4.4 \\
\hline LE & 46.5 & 84.0 & 6.0 & 80.8 & 119.4 & 14.7 \\
\hline $\mathrm{H}$ & 16.2 & 33.3 & 2.3 & 24.9 & 44.6 & 4.3 \\
\hline G & 0.4 & 14.9 & -21.1 & 2.2 & 9.1 & -14.6 \\
\hline
\end{tabular}

Tablo 1, Mart-Nisan 2016 arası 61 günlük dönemi kapsayan veri kullanılarak oluşturulmuştur. Bu dönem, çiçeklenme öncesi 2. yaprak çifti aşamasının son dilimine ve 11.4.2016 tarihinde başlayan çiçeklenme aşamasının büyük kısmına karşılık gelmektedir. Buharlașma hesabında kullanılacak veri sırasıyla öncelikle filtreleme ve ortalama günlük radyasyon değerlerine dönüşüm aşamalarından geçirilmiştir. Bunun ardından net radyasyon değerlerinin sıfırdan büyük olduğu günler için gündüz ortalamaları belirlenmiștir. Hissedilir ısı akısının buharlașma gizli ısı akısından fazla olduğu, yani Bowen Oranı'nın 1'den büyük olduğu günler, veri seti içinde 3 adet olup, sirasiyla $15.3 .2016,17.3 .2016$ ve 28.3.2016 tarihlerine karşılık gelmektedir. Söz konusu durumun, incelenen 61 günlük zaman verisinin neredeyse bir haftasına sıkışmış olduğu görülmektedir [25]. Yukarıdaki eşitliklerle ana hesap aşamaları verilen BREB Yöntemi ile enerji dengesi bileşenleri günlük olarak $\left(\mathrm{W} / \mathrm{m}^{2}\right)$ cinsinden hesaplanmıştır. Bu bileşenlerin içinde yer alan LE ifadesinden günlük gerçek evapotranspirasyon $\left(\mathrm{ET}_{\mathrm{a}}\right)$ değerleri çekilmiș ve ilgili zaman serisi Şekil 4'te verilmiştir.

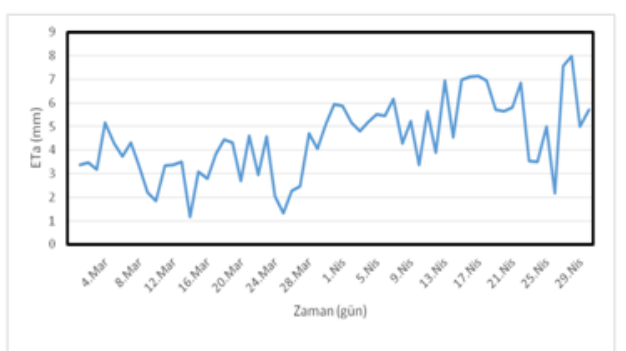

Şekil 4. Kanola Yüzeyinin Mart-Nisan 2016 Dönemi ET a değerleri.
Şekil 4'te görülen $\mathrm{ET}_{\text {a }}$ zaman serisine ait dönem toplamı, $272.1 \mathrm{~mm}$ 'dir. Değişkenin söz konusu aralıktaki ortalama ve standart sapma değerleri ise 4.5 ve $1.1 \mathrm{~mm}$ olmuştur [25].

Net radyasyon değişkeninin ölçüm dönemi maksimumunun gerçekleștiği tarih, 27.4.2016 olarak saptanmıștır. Söz konusu günün enerji dengesi bileşenlerinin 30'ar dakikalık ortalamalar cinsinden zaman serisi, aşağıdaki Şekil 5'te verilmiştir.

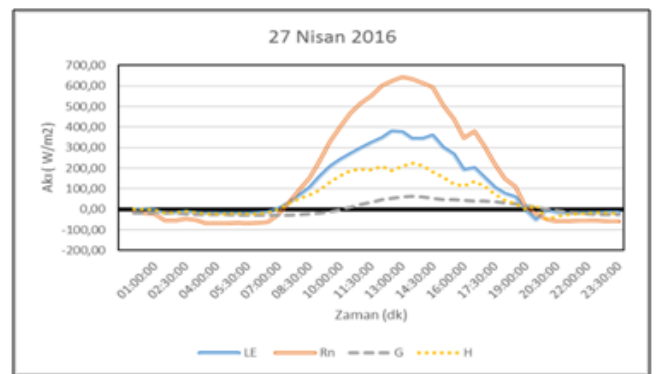

Şekil 5. Ölçüm Döneminin Maksimum Net Radyasyonlu Gününe Ait zaman Serisi.

Beklendiği gibi net radyasyon değerleri güneş doğmadan önce ve batmasından sonraki zaman aralıklarında negatif olmuştur. Aynı zaman aralığında hissedilir ısı akısına zıt yönlü ve aynı değerde (-1) kaydedilen Bowen oranları da, net radyasyon ile toprak isı akısının birbirine hemen hemen eşit değerde olduğu dönemleri temsil etmektedir. Bu durumun geçerliliği gerek enerji dengesi eşitliği ile, gerekse yaklaşık olarak 07:00 ve 19:00 saatleri civarında ölçülen gerçek net radyasyon ve toprak isı akısı verisi incelenerek kolaylıkla anlaşılabilir.

Şekil 5'te verilen ve ölçüm döneminin en yüksek net radyasyon değerlerine erişilen 27.4.2016 tarihinin toplam bitki su tüketimi miktarı da 7.6 mm olarak belirlenmiștir.

Net radyasyonun, ölçüm dönemi içinde minimum değerini aldığı tarih ise, kapalı atmosfer koşullarının geçerli olduğu 14.3.2016 tarihidir (Şekil 6). Radyasyon kazanımının düşüklüğü, toprak ısı akısına da yansımıștır.

Benzer biçimde, hissedilir ısı akısı değişimleri de bu gün boyunca belirgin inișler ve çıkıșlar göstermiş olup; ulaşılan en yüksek değerin, açık günün en yüksek değerinden düşük olduğu saptanmıştır. Hissedilir ısı akısı değerlerinin, buharlaşma gizli ısı akısı ile yaklaşık aynı değere ve zit ișarete sahip olduğu zaman aralıkları da bu gün içinde belirlenmiștir. En düşük net radyasyon kazanımının gerçekleștiği 
DEU FMD 21(61), 97-105, 2019

bu tarihin toplam gerçek evapotranspirasyonu, $1.2 \mathrm{~mm}$ olarak hesaplanmıştır.

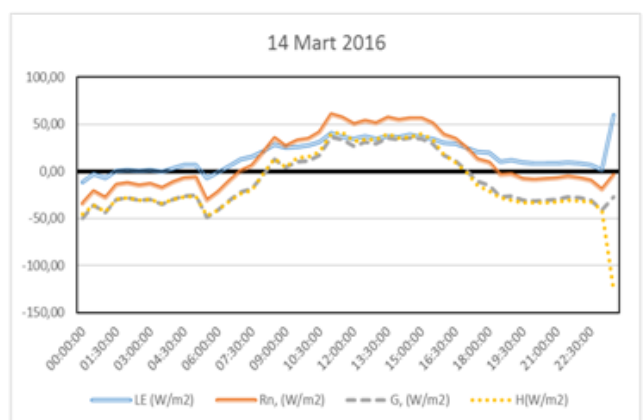

Şekil 6. Ölçüm Döneminin Minimum Net Radyasyonlu Gününe Ait Akıların Zaman Serileri.

İncelenen iki aylık ölçüm döneminin en yağışlı gününün (26.4.2016) net radyasyon seyri de, bu çalıșmanın sonunda ele alınmıștır (Şekil 7). Net radyasyonun bu gün içindeki en yüksek değerlerinin kaydedildiği zaman aralığı (16:00 civarı), yağışın görülmediği, dolayısıyla da bulutluluk etkisinin de azaldığ olmuştur. Beklendiği üzere sıfırdan düşük net radyasyon kayıtlarının sayısı bu günde ölçüm döneminin kalanınkinden fazla olmuştur. $\mathrm{Bu}$ yağışlı gün için toplam evapotranspirasyon (bitki su tüketimi) değeri, 2.3 mm' dir.

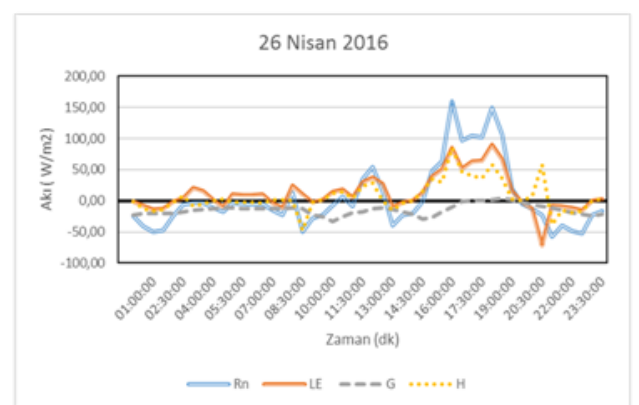

Şekil 7. Ölçüm Döneminin en Yağışlı Gününe Ait Akıların Zaman Serileri.

İncelenen iki aylık dönem için net radyasyon ile ve LE değişkenleri arasındaki ilişki ele alınmış ve aşağıdaki Şekil 8'de görülen seyir ortaya çıkmıştır.

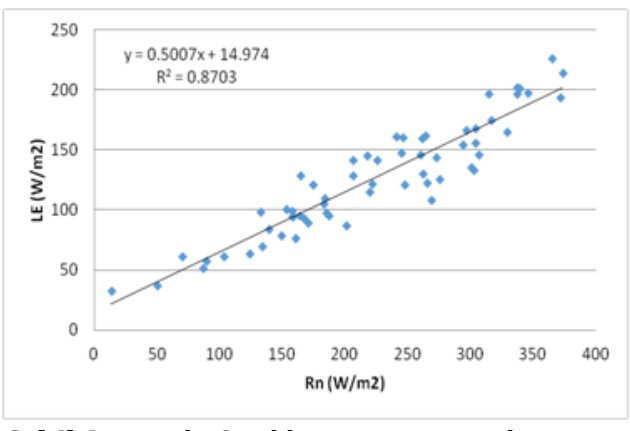

Şekil 8. Kanola Çiçeklenme Döneminde LE-Rn İlişkisi.

Şekil 8'de görülen ve doğrusal Rn-LE ilișkisini gösteren determinasyon katsayısı 0.87 'dir. $\mathrm{Bu}$ durum, buharlaşma ölçüm imkânının sınırlı olduğu zamanlarda yapılacak net radyasyon ölçümlerinin, çiçeklenme döneminde kanola yüzeyi evapotranspirasyonunu hesaplamak için belirli bir hata payı ile kullanılabileceğini göstermektedir. Ancak sadece bir gelişme periyodunda ve belirli bir hata payiyla kullanılabilecek bu ilişki yerine, birçok gelişme dönemi verisine dayanan bir ilişkinin elde edilmesi; daha sağlıklı olacaktır.

\subsection{NDVI değerlerinin incelenmesi}

Bitki yüzeyi üzerinde akılarla eşzamanlı olarak ölçüm dönemi boyunca elde edilen net radyasyon ve NDVI verileri aşağıdaki Şekil 9'da sunulmuştur. Atmosferik koşulların dinamiğinden kaynaklanabilecek etkilerin minimize edilmesi amacıyla her bir günde kaydedilen NDVI değerlerinin maksimumları kullanılmıştır. Şekil 9'da görüldüğü gibi, 18-20.3 2016 tarihleri arasında yükselme eğilimine giren NDVI değerleri, bu durumunu 14.4.2016'ya kadar korumuştur. Bu günü takip eden tarihin (15.4.2016) NDVI değerinin düşük, net radyasyon değerinin ise oldukça yüksek olduğu belirlenmiştir. Yüzey yansıtımını temsil eden NDVI ile; yüzeyin radyasyon kazanımını (ya da kaybını) gösteren net radyasyon arasındaki olası ilişkinin, farklı çevresel etkenlere bağlı olabileceği bu şekilde görülmektedir. Bununla birlikte yüzeyin net radyasyon kazanımının yukarı yönlü eğiliminin, yüzeyin aynı dönemdeki maksimum NDVI değerleri ile birlikte gerçekleştiği, yine Şekil 8'de görülebilir. Çiçeklenme dönemi başlangıcı ile birlikte NDVI değerinde başlayan azalmanın önemli ölçüde NDVI değerinin noktasal olarak ölçülmesinden ve yağıştan kaynaklandığı düşünülmektedir. $\mathrm{Bu}$ bağlamda ölçüm 
DEU FMD 21(61), 97-105, 2019

döneminin yağıș kayıtları incelendiğinde, özellikle yağışsız ancak kapalı günlerin NDVI değerlerinin düşük seyrettiği saptanmıştır.

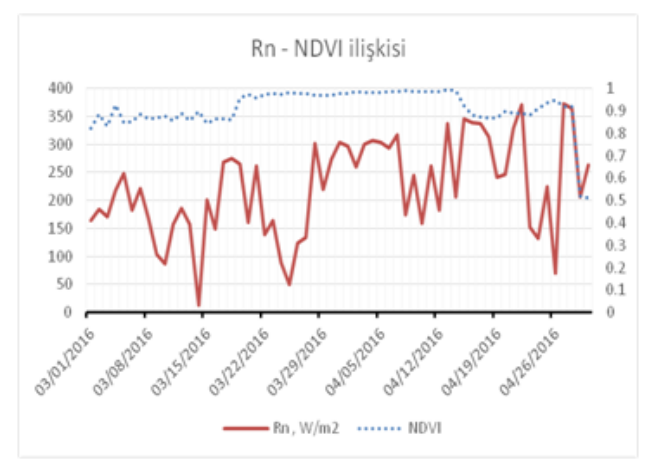

Şekil 9. Ölçüm döneminin Net Radyasyon ve NDVI Değișimleri.

Eşitlik 4'te verilen temele dayanan NDVI verisi, 1 ile 1 arasında değerler almaktadır. Aynı temele bağlı olarak; üst sınıra yakınsayan NDVI değerleri sağlıklı, yoğun, yeşil rengin hâkim olduğu bitki örtüsüne karşıllk gelmektedir. Böylece NDVI verisi kullanılarak sezonluk tarla bitkilerinin verim değerleri de öngörülebilmektedir. Kanola gelişme döneminin iki aylık kısmı için kaydedilen en düșük ve en yüksek NDVI değerleri sırasılyla 0.50 (30.4.2016) ve 0.99 (14.4.2016) olmuştur.

\section{Tartışma ve Sonuç}

Bu araștırma, enerji akısı ve bitki yüzey indeksi değişkenlerinin kanola yüzeyi üzerine analizine yönelik Türkiye'deki ilk çalışma olup, Dünya'da da karşılaştırmalı yoruma olanak sağlayacak benzer çalıșmalara uluslararası literatürde de rastlamak zordur. BREB bağlamında Türkiye'den örnek verilebilecek az sayıda çalışma arasında aynı bölgede, farklı zamanda ve farklı bir yüzey için yürütülmüş bir araştırma gösterilebilir [28]. Kanola yüzeylerinin spektral özelliklerinin biyokütle ile ilișkisinin ortaya konduğu bir çalışma ise, Brezilya'da yürütülmüştür [29]. Kanola NDVI verisinin analizinin [30] yanı sıra, su tüketimi [31] üzerine yapılmış çeşitli çalışmalar da mevcut olup, bu iki vejetasyon dinamiği elemanının birlikte ele alındığı herhangi bir araștırmaya ise rastlanmamıștır. Bu araștırma, net radyasyon ve NDVI değerlerinin bitki su tüketiminin ivmelendiği bir gelişme dönemi bağlamında ele alınması bakımından ayırt edicidir. Çalıșmada, kanola yüzeyinin net radyasyonundaki yükselme eğiliminin, yüzeyin aynı dönemdeki en yüksek NDVI değerleri ile birlikte gerçekleștiği saptanmıştır. Gelecekte farklı bölgelerde ve yüzeylerde yapılacak benzer araştırmalar ile toprak-bitki-atmosfer sistemine yönelik ilişkilerin ortaya konması; gerekliliktir. Bununla birlikte ülkemizde gerçek evapotranspirasyonun belirlenmesinde kullanılan doğrudan ölçme yöntemlerinin ve sistemlerinin kısitlı olması sebebiyle, mikrometeorolojik yaklaşımların yaygınlaștırılmasında yarar vardır. Bitkinin su tüketiminin en fazla olduğu ve yüksek gelişim gösterdiği zaman aralığında gerçekleştirilen bu çalışmada yağışlı gün sayısının azlığı, veri kayıplarını da engellemiștir. Daha önce de belirtildiği gibi; sonuçların genele yayılabilmesi, kanola bitkisi üzerinde mikrometeorolojik yöntemler kullanılarak ve birçok gelişme dönemini kapsayacak șekilde elde edilen verilerin analizi ile mümkün olacaktır. $\mathrm{Bu}$ sebeple Dünya'da bitki-toprak-atmosfer ilişskisini incelemek için yaygın olarak kullanılan söz konusu yöntemlerin, ülkemizde de daha fazla ve etkin biçimde kullanılması gerekmektedir

\section{Teşekkür}

Calıșmaya arazi ve altyapı desteği sağlayan Kırklareli Atatürk Toprak Su ve Tarımsal Meteoroloji Araştırma Enstitüsü Müdürü Dr. Fatih Bakanoğulları'na, araștırmanın Bilimsel Araștırma Projesi (BAP Proje No: 39017) kapsamında maddi olarak desteklenmesini sağlayan Istanbul Teknik Üniversitesi'ne, arazide önceden kurulu olan bir tarımsal meteoroloji istasyonundan eşzamanlı veri teminine imkân tanıyan Prof. Dr. Levent Şaylan'a, Met. Yük. Müh. Serhan Yeşilköy'e, Met. Yük. Müh. Nilcan Altınbaș'a ve veri analizine katkılarından dolayı Met. Müh. Didem Akar'a teşekkür ederim.

\section{Kaynakça}

[1] Aydınșakir, K., Büyüktaș, D. 2005. Lizimetreler ve Bitki Su Tüketimi Çalışmalarında Kullanımı. Derim, Cilt. 22(1), s. 49-58.

[2] Fuchs, M., Tanner, C.B. 1970. Error Analysis of Bowen Ratios Measured by Differential Psychrometry. Agricultural Meteorology, Cilt. 7, s. 329-334.

[3] Ashktorab, W.H., Pruitt, K.T., Paw, U., George, W.V. 1989. Energy Balance Determinations close to the Soil Surface using a Micro-Bowen Ratio System. Agricultural and Forest Meteorology, Cilt. 46(3), s. 259-274.

[4] Todd, R.W., Evett, S. ., Howell, T.A. 2000. The Bowen Ratio-Energy Balance Method for Estimating Latent Heat Flux of Irrigated Alfalfa Evaluated in a SemiArid, Advective Environment. Agricultural and Forest Meteorology, Cilt. 103(4), s. 335-348.

[5] Ünlü, M., Kanber, R., Steduto, P. 2001. Comparing Cotton Evapotranspiration Estimated by Micrometeorological and Water Budget methods. Turkish Journal of Agriculture, Cilt. 25, s. 329-335. 


\section{DEU FMD 21(61), 97-105, 2019}

[6] Gilmanov, T.G., Johnson, D.A., Saliendra, N.Z. 2003 Growing Season CO2 Fluxes in a Sagebrush-Steppe Ecosystem in Idaho: Bowen Ratio/Energy Balance Measurements and Modeling. Basic and Applied Ecology, Cilt. 4(2), s. 167-183.

[7] Rohli, R.V., Hsu, S.A., Lofgren, B.M. Binkley, M.R. 2004. Bowen Ratio Estimates over Lake Erie. Journal Great Lakes Research, Cilt. 30, s. 241-251.

[8] Soares, J.M., De Azevedo, P.V. Da Silva, B.B. 2007 Bowen Ratio-Energy Balance associated Errors in Vineyards under Dripping Irrigation. Revista Brasileira da Meteorogia, Cilt. 22, s. 233-240.

[9] Zeggaf, A. T., Takeuchi, S., Dehghanisanij, H., Anyoji, H., Yano, T. 2008. A Bowen Ratio Technique for Partitioning Energy Fluxes between Maize Transpiration and Soil Surface Evaporation. Agronomy Journal, Cilt. 100(4), s. 988-996.

[10] Zhang, B., Kang, S., Li, F., Zhang, L. 2008. Comparison of Three Evapotranspiration Models to Bowen Ratio-Energy Balance Method for a Vineyard in an Arid Desert Region of Northwest China. Agricultural and Forest Meteorology, Cilt. 148(10), s. 1629-1640.

[11] Wolf, A., Nick, S., Kanat, A. 2008. Effects of Different Eddy Covariance Correction Schemes on a Energy Balance Closure and Comparisons with the Modified Bowen Ratio System. Agricultural and Forest Meteorology Cilt. 148, s. 942-952.

[12] Ünlü, M., Kanber, R., Kapur, B. 2010. Comparison of Soybean Evapotranspirations Measured by Weighing Lysimeter and Bowen Ratio-Energy Balance Methods. African Journal of Biotechnology, Cilt. 9(30), s. 4700-4713.

[13] Akpolat, A., Ünlü, M. 2011. Mikrometeorolojik ve Lizimetre Yöntemleriyle Belirlenen Buğday Bitki Su Tüketimlerinin Karşılaștırılması. Çukurova Üniversitesi Fen ve Mühendislik Bilimleri Dergisi, Cilt. 26(2), s. 183-192.

[14] Fischer, M., Trnka, M., Kučera, J., Deckmyn, G., Orság, M., Sedlák, P., Ceulemans, R. 2013 Evapotranspiration of a High-Density Poplar Stand in Comparison with a Reference Grass Cover in the Czech-Moravian Highlands. Agricultural and Forest Meteorology, Cilt. 181, s. 43-60.

[15] Yan, G., Lin, G., Chen, H., Yang, S. 2014. Seasonal Changes of Energy Fluxes of a Subtropical Mangrove Forest in Zhangjiang Estuary, China. Journal of Chemical and Pharmaceutical Research, Cilt. 6, s. 363-368.

[16] Euser, T., Luxemburg, W.M.J., Everson, C.S., Mengistu, M.G., Clulow, A.D., Bastinaannssen, W.G.M. 2014. A New Method to Measure Bowen Ratios Using High-Resolution Vertical Dry and Wet Bulb Temperature Profiles. Hydrology and Earth System Sciences, Cilt. 18, s. 2021-2032.

[17] Çaldağ, B. 2009. Trakya Bölgesi'nin Tarımsal Meteorolojik Özelliklerinin Belirlenmesi. Istanbul Teknik Üniversitesi, İ.T.Ü. Fen Bilimleri Enstitüsü, Atmosfer Bilimleri Programı, Doktora Tezi, 258s, Istanbul.

[18] Asrar, G., Kanemasu, E. T. and Yoshida, M. 1985 Estimates of Leaf Area Index from Spectral Reflectance of Wheat and Different Cultural Practices and Solar Angles. Rem. Sens. Environ., Cilt. 17, s. 1-11.

[19] Carlson, T. N. and Ripley, D. A. 1997. On the Relation Between NDVI, Fractional Vegetation Cover, and
Leaf Area Index. Rem. Sens. Environ., Cilt. 62, s. 241252.

[20] Ja-Ha, K., Mi Oh, H. and Young Kim, K. 2001. InterAnnual and Intra-Annual Variabilities of NDVI, LAI and Ts Estimated by AVHRR in Korea. Korean Journal of Remote Sensing, Cilt. 17(2), s. 111-119.

[21] Song, D.; Guo, P.; Sheng, H. 2008. Spatial distribution pattern of MODIS-NDVI and correlation between NDVI and meteorology factors in shandong province in China. Book Series: Progress in Electromagnetics Research Symposium, s. 1333-1338.

[22] Şaylan, L., Karayusufoğlu, S., Çaldağ, B., Çaylak, O., Semizoğlu, E., Özkoca, Y.,Bakanoğulları, F. 2011. Uzaktan alglamanın tarımsal meteorolojide kullanılması, Kırklareli örneği, 5. Atmosfer Bilimleri Sempozyumu, Istanbul, 27-29 Nisan, 415-421.

[23] Fritschen, L.J., Simpson, J.R. 1989. Surface Energy Balance and Radiation Systems: General Description and Improvements. J. Appl. Meteorol. Cilt. 28, s. 680689.

[24] Şaylan, L., Çaldağ, B., Bakanoğulları, F., Kaymaz, Z. 2012. Buğday Bitkisinin $\mathrm{CO}_{2}, \mathrm{H}_{2} \mathrm{O}$ ve Enerji Akılarının Belirlenmesi. TÜBİTAK 109R006 No'lu COST Projesi Sonuç Raporu, Istanbul, Ağustos 2012.

[25] Akar, D. 2017. Homojen Bitki Yüzeyi Üzerinde Enerji Dengesi Bileșenlerinin Fenolojik Așamalara Bağlı Analizi. Istanbul Teknik Üniversitesi, Uçak ve Uzay Bilimleri Fakültesi, Meteoroloji Mühendisliği Bölümü, Bitirme Çalıșması, 56s, Istanbul.

[26] Prueger, J.H., Hatfield J.L., Aase, J.K., Pikul, J.L. 1997. Bowen-Ratio Comparisons with Lysimeter Evapotranspiration. Agronomy Journal, Cilt. 89(5), s. 730-736.

[27] Steduto, P., Hsiao, T.C. 1998. Maize Canopies under two Soil Water Regimes: IV. Validity of Bowen Ratio-Energy Balance Technique for Measuring Water Vapor and Carbon Dioxide Fluxes at 5-min Intervals. Agricultural and Forest Meteorology, Cilt. 89(3), s. 215-228.

[28] Özkoca, Y. 2015. Mikrometeorolojik Yöntemlerle Bitkilerin Enerji Akılarının Belirlenmesi. Istanbul Teknik Üniversitesi, Fen Bilimleri Enstitüsü, Atmosfer Bilimleri Programı Yüksek Lisans Tezi, 76 s, Istanbul.

[29] Pinto, D.G., Fontana, D.C., Dalmago, G.A., Santi, A. 2017. Correlations between spectral and biophysical data obtained in canola canopy cultivated in the subtropical region of Brazil. Pesquisa Agropecuaria Brasiliera. Cilt. 52 (10), s. 825-832.

[30] Sulik, J.J., Long, D.S. 2016. Spectral considerations for modeling yield of canola. Remote Sensing of Environment. Cilt. 184, s. 161-174.

[31] Banuelos, G.S., Bryla, D.R., Cook, C.G. 2002. Vegetative production of kenaf and canola under irrigation in central California. Industrial Crops and Products. Cilt. 15(3), s. 237-245. 